Article

\title{
When Is an Innovative Urban Mobility Business Model Sustainable? A Literature Review and Analysis
}

\author{
João Valsecchi Ribeiro de Souza ${ }^{1, *(1)}$, Adriana Marotti de Mello ${ }^{2}(\mathbb{D})$ and Roberto Marx ${ }^{1}$ \\ 1 Department of Production Engineering, School of Engineering, University of São Paulo, \\ São Paulo 05508-010, Brazil; robemarx@usp.br \\ 2 Business Administration and Accounting, School of Economics, University of São Paulo, \\ São Paulo 05508-010, Brazil; adriana.marotti@usp.br \\ * Correspondence: joao.valsecchi.souza@usp.br
}

Received: 29 December 2018; Accepted: 20 March 2019; Published: 23 March 2019

check for updates

\begin{abstract}
Although researchers have increasingly examined how business models promote sustainable urban mobility through innovation, the literature has focused less attention on what constitutes a sustainable and innovative business model in the context of urban mobility. To fill this research gap, this article aims to answer the following research question: what elements characterize sustainable and innovative business models in the field of urban mobility? To identify whether and to what extent the existing intersection between business models and sustainable urban mobility literature contributes to the development of this concept, a systematic review and analysis of the literature was conducted. The results indicate that the following aspects contribute to the sustainability of an urban mobility business model: favoring the use of clean energy; maximizing the use of transport resources and capabilities; encouraging substitution using sustainable modes; offering service orientation and functionality; articulating initiatives that address the needs of a wide range of stakeholders in transport systems; reducing travel demands; extending benefits to society and the environment in a systemic perspective; and developing scale-up mobility solutions.
\end{abstract}

Keywords: sustainable urban mobility; business model; business model innovation; sustainable business models; literature review

\section{Introduction}

Urban mobility has a central role in developing more sustainable cities, especially considering that the production and consumption of goods and services in major urban centers requires sustainable solutions that enable large masses of people to travel [1,2].

Transportation, especially based on internal combustion engines, is linked to high levels of $\mathrm{CO}_{2}$ emission, energy consumption, and negative impacts on people's health and climate change [3]. The challenge of providing alternatives that promote sustainable urban mobility while reducing the dependence on private car use (without compromising the convenience of this model) has been established as a key issue in studies on this topic because the use of the previous mode has produced significant reductions in people's travel quality standards and has directly affected the economic, environmental, and social functions of cities. There is a growing awareness of the need for a transition to more sustainable mobility systems in cities [2,4-6].

Thus, the challenges of sustainable urban mobility require approaches that extend beyond the optimization of resources used in transport planning and avoid dealing with issues in isolation, a recurrent feature in the seminal literature on mobility and transport. These needs for new approaches in urban mobility, which increase quality in transport, while reducing environmental and economic 
impacts, generate demand for innovation in urban mobility and attract the interest of various actors in society, thus enabling opportunities to generate new business models, in order to allow the diffusion of those innovations in the market [1].

Although the literature has increasingly indicated the key role of business models in promoting sustainable urban mobility through innovation in the field, less attention has been focused on what constitutes a sustainable and innovative business model in the context of urban mobility. There is a considerable amount of knowledge on what makes innovation sustainable at the firm level, but less is known about how sustainable innovations can be implemented and how both economic feasible and sustainable business situations can be created for those involved while actually enabling those innovations to be diffused successfully in markets. The research on business models recognizes that this concept reflects the essential elements for understanding, developing, and commercializing innovations considered sustainable; however, the models do not necessarily incorporate sustainability during their design process (value proposition) or during the execution of these models (delivery and value capture) thus limiting the clarity of the features that characterize innovative and sustainable business models, especially in the field of urban mobility [7-9].

This article, therefore, attempts to fill this gap in the literature by answering the following research question: What are the aspects of a sustainable and innovative business model in the field of urban mobility?

A literature review was conducted to enable the following: (1) a discussion on the role and relevance of sustainable and innovative business models in relation to aspects that characterize sustainable urban mobility, (2) an investigation into the intersection between business models and sustainable urban mobility to identify elements that should be considered by such models as sustainable and innovative in this field, and (3) an investigation into how these elements synthesize research and guide future investigations.

Although this article focuses on advances in theory, its contribution is directed not only toward the literature on the subject but also toward public policy decision makers and practitioners. The research seeks to promote a closer approximation between sustainable management literature and mobility and transport literature. For practitioners, the research discuss opportunities for organizing new businesses focused on sustainable urban mobility. For public policy makers, the findings discuss alternatives to encourage business models aimed at promoting sustainable mobility.

The first part of the article explains and justifies the research methodology adopted. The second and third sections provide a literature review on sustainable urban mobility and business models, respectively, and the next section discusses the results. In the conclusion, the contributions, limitations, and prospects for future research are presented.

\section{Basic Concepts and Terminology}

To establish the assumptions underlying this research, basic concepts and terminology are first defined. In this research, the term urban mobility is applied to refer to the spatial dimension of mobility, which is composed of various terms and conditions of temporary relocations of people in the context of urban space [10]. Urban mobility refers not only to the aspects that allow people to get around but also to people's ability to reach their destinations by using the infrastructure available in the urban space.

According to the United Nations World Commission on Environment and Development report [11] (p. 16), sustainable development refers to "development that meets the needs of the present without compromising the ability of future generations to meet their own needs". The definition contains two key concepts in the term "needs": (1) the notion of priority in relation to the essential needs of people and (2) the idea that the state of technology and social organization has imposed limitations on the environment's ability to meet present and future needs [11]. Thus, sustainable urban mobility is essential to the broader challenges of sustainable development [12]. 


\section{Materials and Methods}

\subsection{Rationale for Literature Review, Analysis, and Definition of Characteristics}

No other literature reviews have clearly and systematically articulated the concepts required to respond to the research question, therefore limiting an essentially empirical research theme. Thus, a literature review was conducted to focus on the qualitative aspects of the articles analyzed through content analysis.

The function of the literature review is to clearly delineate what research must be conducted in an area of study and why it is important, as well as to articulate the practical significance of research, to synthesize previous research to provide a new perspective, and to critically analyze the research methods used in previous investigations [13].

Moreover, the role of a literature review is to seek new research avenues, identify relevant variables for the theme, relate practical ideas, or place research in a historical context to show familiarity with what has been developed [14].

Certain variables must be controlled to ensure accuracy when conducting literature reviews. To guide the use of techniques for this type of research, six characteristics may be applied: focus, goal, perspective, coverage, organization, and audience [14]. Table 1 summarizes these variables and the ways in which they are monitored in this study.

Table 1. Ways of using and controlling qualitative variables during a literature review.

\begin{tabular}{|c|c|c|}
\hline Variable & Definition & $\begin{array}{c}\text { Ways of Using and Controlling Variables in } \\
\text { This Research }\end{array}$ \\
\hline Focus & $\begin{array}{l}\text { What aspects are focused on in the review, } \\
\text { avoiding simple bibliographic citation }\end{array}$ & $\begin{array}{l}\text { Concepts that have a central discussion on } \\
\text { aspects that characterize (1) sustainable urban } \\
\text { mobility and (2) business models, including those } \\
\text { that intrinsically incorporate the issue of } \\
\text { innovation and those that discuss aspects that } \\
\text { make them more sustainable }\end{array}$ \\
\hline Goal & $\begin{array}{l}\text { Whether it allows the integration or } \\
\text { generalization of findings to resolve a } \\
\text { debate within a study field }\end{array}$ & $\begin{array}{l}\text { Integrating findings across the existing literature } \\
\text { to contribute to the development of the research } \\
\text { on a theme. }\end{array}$ \\
\hline Perspective & Researcher neutrality & $\begin{array}{l}\text { Neutrality is pursued through detailed } \\
\text { description and use of scientific rigor regarding } \\
\text { the employed research techniques. }\end{array}$ \\
\hline Coverage & Limits considered in the review & $\begin{array}{l}\text { Literature analysis is essentially qualitative } \\
\text { (content analysis). }\end{array}$ \\
\hline Organization & Text organization and structure & $\begin{array}{l}\text { Findings summarizing for each reviewed article } \\
\text { Analysis and discussion of intersection points in } \\
\text { the literature. }\end{array}$ \\
\hline Audience & $\begin{array}{l}\text { Knowledge and consideration of the } \\
\text { research target audience. }\end{array}$ & $\begin{array}{l}\text { Researchers interested in the development of } \\
\text { scientific knowledge on sustainable and } \\
\text { innovative business initiatives in the field of } \\
\text { urban mobility. }\end{array}$ \\
\hline
\end{tabular}

\subsection{Article Search and Selection}

The search for reference articles was performed in three main steps: searching research terms and filters in the databases through several iterations, reading titles and abstracts carefully to find relevant articles, besides selecting and fully reading central articles to enable the coding process described in next section. These steps were guided by the following delimitation and criteria:

- $\quad$ English-only, blind refereed scientific articles published in peer-review journals, indexed in the Scopus database, and preferably published after 2005 were considered, aiming to have more up-to-date and state-of-the-art literature, besides assuming that the publications on the themes analyzed have grown considerably in the past decade; 
- The terms searched in the articles' titles, abstracts, and keywords were: "sustainable urban mobility" or "sustainable mobility" or "sustainable and transport" with "business model"; "sustainable urban mobility" or "sustainable mobility" or "sustainable" with "transport"; "business model" and "innovation" and "review" and "sustainable business model";

- Articles in the following sub-areas were not considered: health, mathematics, neuroscience, chemistry, biology, agricultural and medicine.

- Only articles in which the central discussion aimed at the characterization of the searched-for concepts were considered. Therefore, articles that addressed the themes but did not add to the characterization of the concepts were not prioritized in the analysis;

- For articles related to urban mobility and sustainable transport, quantitative and essentially technical studies on modeling and transport simulations as well as on ticketing and pricing were excluded because they did not contribute to the focus of the discussion. The research prioritized studies that aimed to understand which are the relevant dimensions and aspects to delimit and to characterize sustainable urban mobility;

- For articles related to sustainable business model, many of the articles found were included, since it is a recent literature and with fewer references, although it has grown considerably in recent years. The research prioritized studies that aimed to understand which are the relevant dimensions and aspects to delimit and to characterize sustainable business models; and

- For the terms whose results had a high volume of items and for which other isolated revisions had been conducted and extensively discussed—such as business model innovation literature-articles that already contemplated these revisions were prioritized.

Taking the established delimitation into account, 57 papers were selected to comprise the literature review. A detailed search and selection process is described in Appendix A.

\subsection{Content Analysis}

Once the reference articles to support the research were selected, a model was adopted to analyze their content [15]. In this model, five steps were taken:

1. Starting point - the question and objective of research that guides all the decisions and criteria used in subsequent steps;

2. Definition of aspects of main categories and subcategories based on theory-determines, from existing theory, in which categories and subcategories the collected material is placed;

3. Establishing definitions and coding rules for the analyzed material-reference articles are then classified according to the categories and subcategories defined;

4. Interpretation of results-results found in the literature that contribute to the research objective are discussed and interrelated; and

5. Review of categories, subcategories, and coding rules-if needed, these elements are reviewed from the results.

In this research, we began with certain dimensions and categories based on the initial concepts presented, and reviewed them during the initial analysis of the papers. Internal validity was established and the results were discussed among the authors, especially in steps 3 and 4, because it might be necessary to redo them several times, aiming to reduce the risk of divergent decisions on how paper articles were understood and classified. Coding rules were defined to ensure that final content analysis decisions support a clear relation with the existing literature. This method described establishes the background for the literature review presented herein. Content analysis codes tree is described in Appendix B. 


\subsection{Analysis of Collected Material and Intersction between Sustainable Urban Mobility and Business Model} Literature Categorization

The analysis model defined - that is, the final categories and subcategories organized from the literature review-is separated into three parts: sustainable urban mobility, sustainable business models, and business model innovation. The latter two were divided in this way because the literature on business models does not necessarily incorporate aspects related to innovation or sustainability with business models concurrently. Therefore, this subdivision is indispensable in ensuring that these constructs are contemplated. For each of the parts, the focus was to identify which elements in the literature allow for characterizing these concepts to later delimit their intersection and, thus, build an integrated concept regarding the aspects that constitute innovative and sustainable business models of urban mobility.

The results described in Section 3 are organized according to the analytic categories and subcategories proposed and represent the results of the individual analysis for each literature, as shown in Figure 1. The categories and subcategories were defined applying a mix of deductive approach based on the theoretical background-specially for the subcategory "dimensions and key activities" [16] present in business model innovation and sustainable business models review-and a inductive approach from the content analysis—for all other subcategories (see Appendix B).

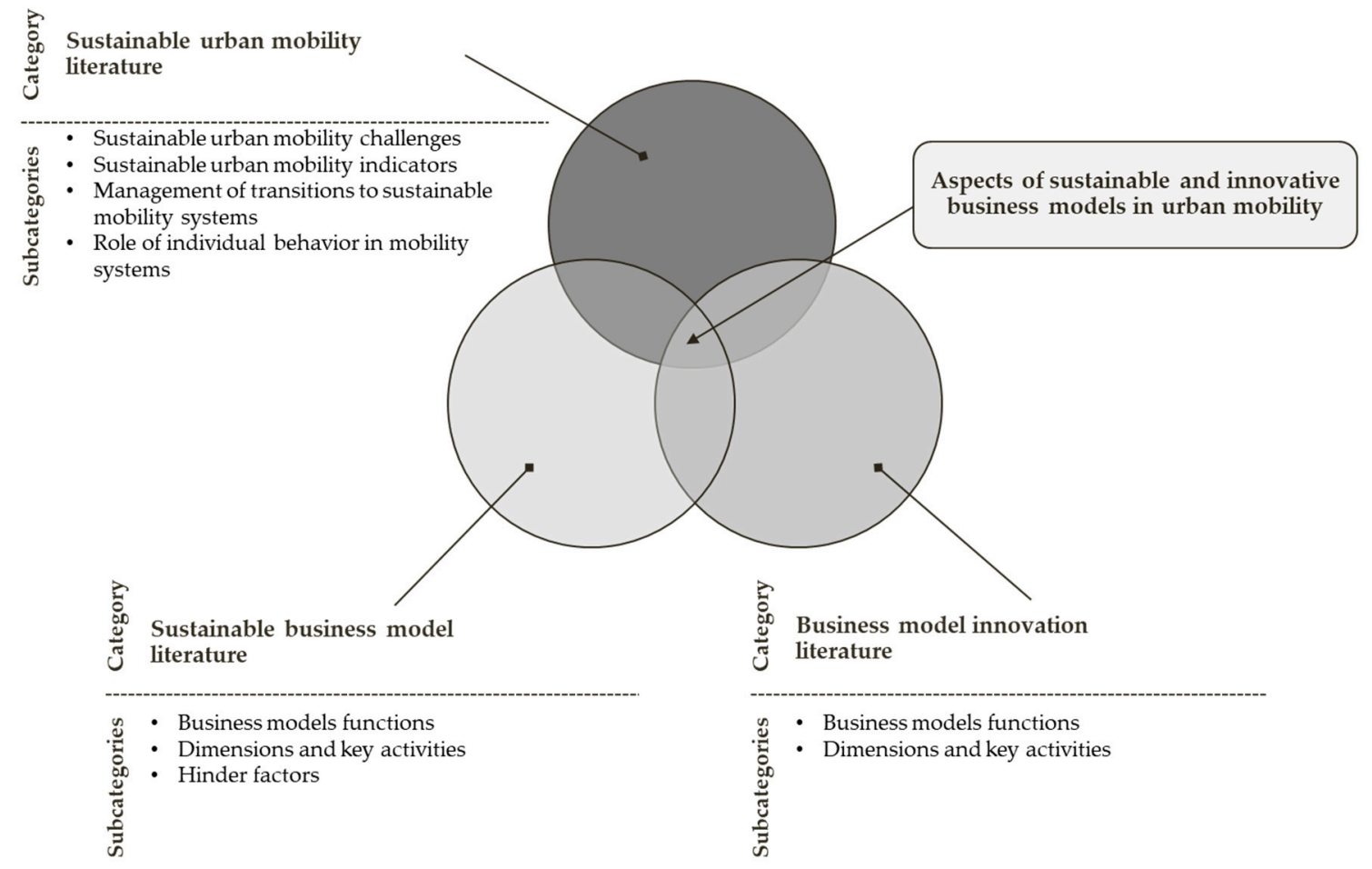

Figure 1. Conceptual analysis model proposed for the literature review.

Then, in order to identify which elements should be considered by business models to be both sustainable and innovative in the field of urban mobility, we explored the intersection literature results in Section 4, applying the sustainable business models archetypes described by Bocken et al. [17] as a starting point to describe in the context of urban mobility which elements constitute a sustainable and innovative business model. The whole research flow is presented in Figure 2. 


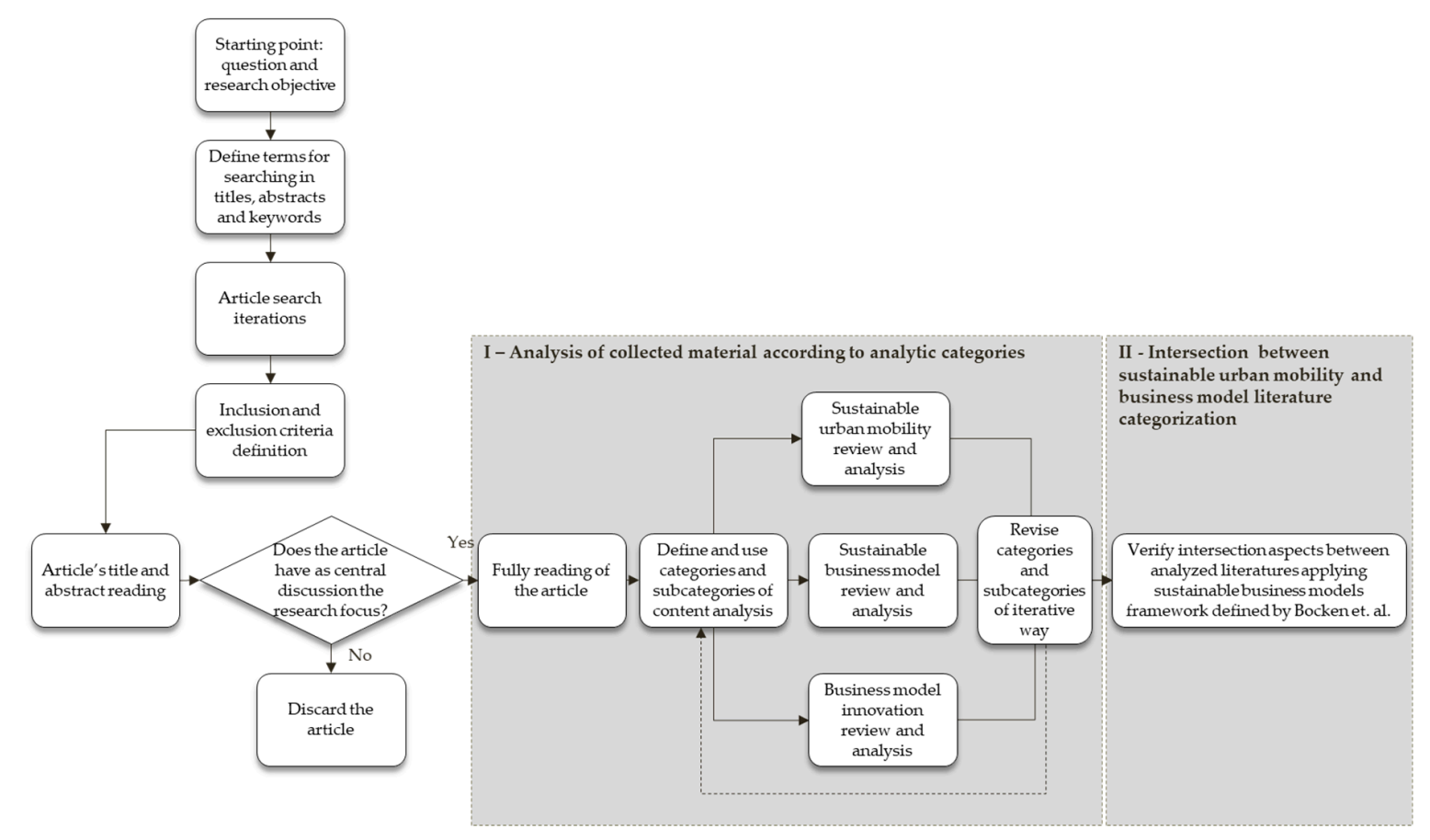

Figure 2. Research flow applied for the literature review.

\section{Analysis of Collected Material According to Analytic Categories}

\subsection{Sustainable Urban Mobility}

Broad research agendas on sustainable urban mobility characterize the study on this field, which prevents applying only one or a few lines of research in a separated manner [6]. Thus, to identify the elements that delimit sustainable urban mobility, the reference articles selected were placed into four subcategories that are not mutually exclusive: (1) articles that discuss the challenges of urban mobility becoming more sustainable; (2) articles that analyze which indicators can be applied to assess the sustainability of mobility systems; (3) articles that articulate sustainable urban mobility from a socio-technical approach to transitions; and (4) articles that discuss the essential role of individuals in achieving sustainable urban mobility.

\subsubsection{Sustainable Urban Mobility Challenges}

Authors interested in defining sustainable urban mobility challenges usually refer to integrated actions that should be conducted in the following areas: demand management, modal shifts towards sustainable alternatives, technological innovation, along with actions of public institutions and the government. The main ideas discussed by authors are briefly listed throughout this section.

Several authors suggest that sustainable urban mobility should be promoted through solutions that reduce the need to travel, that is, the relocation demands $[2,3,10]$. These solutions include the promotion of non-travel activities such as telecommuting, teleshopping, and other services [6].

Moreover, authors also encourage the substitution of certain transport modes, especially regarding private cars. The importance of intermodal integration is part of this context [18]. This includes the availability of integrated and customized transportation in specific situations; the encouraged use of vehicles that use clean energy, such as electric cars and cycling; and other sustainable alternatives complementary to the traditional public transport [1,2,10,19-21].

Regarding technology, the discussion relates to the search for greater efficiency in existing transport systems, in which technological innovation and changes in user behavior have a primary role. Furthermore, intelligent transport systems can develop mechanisms that restrict traffic in central metropolitan areas, maximize public transport service efficiency, rapidly provide information for users 
to make decisions by using mobile technologies, and strengthen laws related to traffic management, which are crucial points of technological integration $[1-3,5,6]$. Regarding this aspect, the role of business models in promoting competitive alternatives to private cars through the dissemination of travel information, fare integration, vehicle-and bicycle-sharing models, incentives to reduce automobile ownership, and new integrated services for transport solutions are also emphasized [5,22].

From a public policy perspective, some authors advocate the favorable role of holistic forms of implementation and the inter-sectorial policies relevance, including the private sector, which ensure sustainable transport infrastructure, seeking the integration of local needs and values that affect policymaking at an institutional level [23-25]. Other research highlights the challenge of understanding what incentives are needed to accommodate the full range of actors involved in shared mobility contexts [26]. Additionally, for public policy design, it is also important to contemplate the challenge of integrating transportation planning with social needs-through accessibility, allocation, and planning of public space, and opportunities for social engagement-because the logic of transport planning that has prevailed in the majority of cities favors a model of car dependence, with limited opportunities to develop sustainable initiatives [3,5]. However, other authors consider that even though the government has an important role in building systems that provide better sustainable urban mobility, this transition is intrinsically linked to a social learning process involving multiple stakeholders, focusing on the following elements: the system as a whole; its spatial characteristics, infrastructure, and technology options; the individual needs of mobility and access; cultural norms and institutions; and their mutual interdependence [27].

\subsubsection{Sustainable Urban Mobility Indicators}

A number of reference articles address the development and application of indicators related to sustainable mobility (see [28]). In this sense, the construction of indicators to assess the sustainability of mobility systems requires their impacts to be considered in a balanced way, in all the dimensions of sustainable development-economic, environmental, and social-because it is not possible to assess sustainable transport without considering the integration of these dimensions [29].

In a comparative study on sustainable mobility indicators in European cities [30], some aspects are reinforced, such as: the relevance of metrics related to the presence of multimodal services; lift and vehicle sharing; the definition of urban areas with controlled access to private car to manage the transport demand; the introduction of clean vehicles and fuels; the encouraged use of bicycles; and transport system information provisions for users, developing polycentric urban systems instead of a single-center one [31], as well as addressing the issues involved in sustainable mobility reviewed in the previous section.

Another relevant point is that large urban centers generally pose greater challenges for achieving sustainability in their mobility systems as compared to smaller cities. This validation reinforces the importance of adopting measures that relate to the management of urban transport demand, as well as the application of sustainable solutions to these contexts [29,32].

\subsubsection{Management of Transitions to Sustainable Mobility Systems}

Anchored in the socio-technical systems approach to transitions, especially given the reasons elaborated by many authors (see [33-35]), several articles on sustainable mobility suggest that answers to the challenges that ensure transition to sustainable urban mobility systems require more than changes from the point of view of technological development. Notably, they should instead be addressed from a systemic point of view and consider aspects that influence current mobility regimes, such as user preferences, policies, existing technologies, market rules, cultural, and scientific aspects, and regulatory mechanisms, to address current and potential future challenges [1,33,36-38].

In this sense, a socio-technical approach to transitions should address policies oriented toward the construction of sustainable mobility models and must be more concerned with long-term results than with short-term ones $[39,40]$. This approach should be understood not only as an instrument but also 
as a management model for sustainable development, concerned with addressing persistent problems in socio-technical systems. Sustainable mobility requires knowledge from learning and expertise other than that currently applied to increase reflection on the management systems [41].

Notably, according to a study on the implementation of a socio-technical approach in Brazilian cases, this approach rarely considers the aspects of local realities involved in the socio-technical regime, such as different trajectories and the operational and institutional contexts of actors involved in sustainable urban mobility innovation processes, which are also relevant when analyzing influences on existing regimes [42].

\subsubsection{Role of Individual Behavior in Mobility Systems}

The latter aspect observed in the literature review concerns research aimed at analyzing the role of individual behavior in sustainable urban mobility, beginning with the premise that travel needs and individual behavior direct the aspects that characterize mobility systems. Individuals, in turn, prioritize options considered unsustainable-particularly regarding private car use-which directly affects the development of sustainable mobility. Addressing individuals' internal decision-making processes in relation to travel patterns is recommended, as individual choices can be influenced by numerous variables, including travel needs, standard of living, and access to information, among others $[43,44]$. However, transportation service quality is also an essential factor that influences individuals' decision-making and should thus also be considered [4].

\subsection{Business Model Innovation}

Organizations recognize the emergence of dynamic markets in which competitiveness must be based on variables in addition to price: intangible customer solutions, complementary to products that are able to meet their needs; and demand, because customers operate in markets that are undeveloped. Due to this context, business models have recently received more attention [45].

\subsubsection{Business Model Functions}

Business models have been widely accepted and used in the literature; however, they are often applied in completely distinct ways and contexts. Business model can be defined as a conceptual tool that contains a number of interrelated elements. These allow for expressing an organization's business logic - how an organization "does business" — by describing the mechanisms through which organizations create and sustain value [46]. Business models help organizations add value, attract customers to pay for this value, and manage profit from this relationship [45].

Thus, business models are not strategies themselves but rather guidelines that reflect strategy. They are the main key to decode, understand, and effectively communicate strategy both within an organization and throughout its business ecosystem; that is, business models should reflect an organization's strategic choices and operational implications [47].

\subsubsection{Dimensions and Key Activities}

Numerous authors have sought to represent business model dimensions and key activities. In attempting to establish an integrated model to represent these elements, an author defined three key business model aspects: (1) value proposition-what an organization intends to deliver to its customers and the reasons why they would pay for it; (2) value creation-how an organization articulates resources, capabilities, processes, and networks of customers and suppliers to create and deliver the value intended; and (3) value capture-how an organization generates revenue and profit from activities [16].

Developing a successful business model is not sufficient to guarantee competitive advantage [45]. In this context, business model innovation arises. Business model innovation emerged because models could no longer be seen as static by their managers, requiring continuous reinvention in response to 
turbulent and dynamic environments. Thus, business models assume the role of innovation facilitators, even as units of analysis or starting points to define innovation strategies [48-51].

\subsection{Sustainable Business Models}

Incorporating aspects of sustainability, business models play a fundamental role in understanding and developing sustainable innovation beyond an organizational level by integrating consumption and production systems [8]. Nevertheless, business models do not necessarily incorporate sustainability issues; consequently, it is essential to understand the aspects that should be taken into account for them to be characterized as sustainable [7].

\subsubsection{Business Model Functions}

The literature examining sustainable business models has grown substantially in recent years, particularly because of their association with the performance of key functions in organizations-although there are still many opportunities for applying and experimenting with the logic of sustainable business models-[52,53], including the following: (1) the commercialization and introduction of sustainable innovations in the market [7]; (2) the assurance of a better balance of objectives for all stakeholders-including the environment and society, not only for customers-to eliminate conflicts or negative outcomes and to enable better sustainability at an organizational level [9,54-58]; and (3) the direction and implementation of corporate innovations towards sustainability, which contribute to its incorporation in organizational processes and purpose, serving as a key factor that generates competitive advantage [17]

\subsubsection{Dimensions and Key Activities}

Therefore, for business models to be considered sustainable, the literature indicates that models should incorporate specific aspects in their dimensions and key activities and consider the interrelation of these aspects with the social, environmental, and economic dimensions of sustainable development. Table 2 summarizes the characteristics of sustainable business models according to their dimensions [16].

Some authors advance the discussion on sustainable business models by noting that there is no broad approach on how and why organizations have incorporated sustainability into their business models, although researchers have recently examined this topic [59]. A research defined eight archetypes or categorizations by which an organization can develop a sustainable business model from an approximation of standards and attributes in several categories: maximizing material and energy efficiency; creating value from "waste"; using renewable sources; delivering functionality and services, rather than ownership; adopting a management and leadership role along with stakeholders; encouraging sufficiency in consumption and production relations; re-purposing the business for society/environment; and developing scale-up solutions [17]. 
Table 2. Characteristics of sustainable business models according to their dimensions and key activities.

\begin{tabular}{|c|c|c|c|}
\hline & Value Proposition & Value Creation & Value Capture \\
\hline $\begin{array}{l}\text { Characteristics of } \\
\text { sustainable business models }\end{array}$ & $\begin{array}{l}\text { Measurable environmental or social values aligned } \\
\text { with economic values [7]. } \\
\text { It helps to describe, analyze, manage, and } \\
\text { communicate a sustainable value proposition to all } \\
\text { customers and other firm stakeholders [58]. } \\
\text { It delivers services and functionality rather than } \\
\text { ownership [17] } \\
\text { Sustainability strategies are adopted in participation } \\
\text { with a diverse number of local groups, which } \\
\text { provides better opportunities for learning and } \\
\text { creating innovative solutions [57,60] } \\
\text { Value proposition reflects the triple bottom line } \\
\text { approach. It encompasses a systemic perspective } \\
\text { beyond the firm [7] }\end{array}$ & $\begin{array}{l}\text { Customers and other stakeholders are encouraged to take } \\
\text { responsibility for their consumption practices [7]. } \\
\text { The increase in firm profitability is provided through the efficient use } \\
\text { of resources (human, financial, and raw materials); projects; effective } \\
\text { enterprises; and good management, planning, and control [56]. } \\
\text { It demands responses to societal needs, including all stakeholders [56]. } \\
\text { Learning and development of capabilities are part of the stakeholder } \\
\text { relationship process, which is a way to deal with challenges of } \\
\text { coordination and collaboration [57]. } \\
\text { Suppliers adapt, engage, and get actively involved in the activities and } \\
\text { principles related to management of the sustainable supply chain [7]. } \\
\text { It proactively engages with all stakeholders by ensuring social } \\
\text { involvement through supplier accreditation programs, community } \\
\text { development, and other aspects that can be incorporated into } \\
\text { intangible product value [17]. } \\
\text { Relationships with customer are organized around the shared } \\
\text { recognition of challenges to sustainability at various stages of the } \\
\text { development of markets [7]. } \\
\text { Focus on technological innovation, consumption reduction, } \\
\text { prioritization of renewable resources, demand-oriented models, and } \\
\text { closed-loop systems [61]. } \\
\text { It finds mechanisms that convince stakeholders to change from } \\
\text { "single" to "multiple objectives" [57]. } \\
\text { Harmful and irreversible changes to the environment are avoided } \\
\text { through the efficient use of natural resources, promoting renewable } \\
\text { resources, soil and water protection, and the skillful management of } \\
\text { residues [56]. }\end{array}$ & $\begin{array}{l}\text { It captures economic value while maintaining or } \\
\text { regenerating social, environmental, and } \\
\text { economic capital beyond the firm [58]. } \\
\text { It enhances the role played by the government } \\
\text { at all levels, including incentive mechanisms } \\
\text { and exemptions [57] } \\
\text { It reflects an appropriate distribution of costs } \\
\text { and benefits among stakeholders as well as } \\
\text { social and environmental impacts generated by } \\
\text { firms [7]. } \\
\text { It uses the triple bottom line approach to } \\
\text { measure business model performance [ } 61,62] \text {. }\end{array}$ \\
\hline
\end{tabular}




\subsubsection{Hindering Factors}

Other authors discuss the factors that might hinder sustainable business models, such as the non-involvement of stakeholders and shareholders in the process of value proposition and creation [58], the excessive systems of tax [61], resistance to the introduction of technology and new business models [7], gap skills and incentives [63], and specific forms of value uncaptured [64].

\section{Intersection between Sustainable Urban Mobility and Business Model Literature Categorization}

As we presented in Section 3.3.2, our research identified the main dimensions and key activities that should be taken into account when defining a business model as sustainable. The article published by Bocken et al. in 2014 [17] emerged as result of our research. This article is highly cited (it is the most cited and downloaded article from the Journal of Cleaner Production), being used since its publication by many authors to categorize and explain sustainable business models in different cases and contexts.

In this section, we departed from the dimensions presented by Bocken et al. [17] and applied those dimensions to analyze our sample of intersection articles about sustainable and innovative business models in urban mobility.

As a result, we contributed to understand how each archetype can be applied to the specific aspects that characterize sustainable and innovative business models in urban mobility, as we explain in Table 3.

Table 3. Model for analysis of intersection between analyzed literature.

\begin{tabular}{|c|c|c|}
\hline $\begin{array}{l}\text { Sustainable Business Model } \\
\text { Archetypes [17] }\end{array}$ & $\begin{array}{l}\text { Sample of Articles That Contribute to Discuss } \\
\text { Intersection between Analyzed Literature }\end{array}$ & $\begin{array}{l}\text { Aspects of Sustainable and Innovative } \\
\text { Business Model in Urban Mobility }\end{array}$ \\
\hline $\begin{array}{l}\text { 1. Maximize material and } \\
\text { energy efficiency }\end{array}$ & $\begin{array}{l}\text { Jablonski, A. [56] } \\
\text { Stubbs, W.; Cockling, C. [61] }\end{array}$ & Favoring the use of clean energy \\
\hline 2. Create value from waste & $\begin{array}{l}\text { Boons, F.; Lüdeke-Freund, F. [7] } \\
\text { Bocken, N.M.P.; Short, S.W.; Rana, P.; Evans, S. [17] }\end{array}$ & $\begin{array}{l}\text { Maximizing the use of transport resources } \\
\text { and capabilities }\end{array}$ \\
\hline $\begin{array}{l}\text { 3. Substitute with renewable } \\
\text { and natural process }\end{array}$ & $\begin{array}{l}\text { Jablonsnki, A. [56] } \\
\text { Stubbs, W.; Cocklin, C. [61] } \\
\text { Banister, D. [2] }\end{array}$ & $\begin{array}{l}\text { Encouraging substitution using } \\
\text { sustainable modes }\end{array}$ \\
\hline $\begin{array}{l}\text { 4. Deliver functionality rather } \\
\text { than ownership }\end{array}$ & Bocken, N.M.P.; Short, S.W.; Rana, P.; Evans, S. [17] & $\begin{array}{l}\text { Offering service orientation and } \\
\text { functionality }\end{array}$ \\
\hline 5. Adopt a stewardship role & $\begin{array}{l}\text { Hull, A. [25] } \\
\text { Stubbs, W.; Cocklin, C. [61] }\end{array}$ & $\begin{array}{l}\text { Articulating initiatives that address the } \\
\text { needs of a wide range of stakeholders in } \\
\text { transport systems }\end{array}$ \\
\hline 8. Develop scale-up solutions & $\begin{array}{l}\text { Zito, P.; Salvo, G. [29] } \\
\text { Rodrigues da Silva, A.N.; Azevedo Filho, M.A.N.de; } \\
\text { Macêdo, M.H.; Sorratini, J.A.; da Silva, A.F.; Lima, J.P.; } \\
\text { Pinheiro, A.M.G.S [32] }\end{array}$ & Developing scale-up mobility solutions \\
\hline
\end{tabular}

\subsection{Favoring the Use of Clean Energy}

Energy efficiency maximization is directly related to reducing demand for energy and resources employed in mobility systems-vehicles that are more energy efficient and that consume clean fuels such as electricity - which meet with the aspects already discussed in other studies (see [56,61]). In addition, part of this archetype is the development of business models that enable users to adopt sustainable alternatives integrated with other modes through actions that restrict the use of internal combustion engine private vehicles, consequently improving travel conditions and reducing emissions that pollute the environment. 


\subsection{Maximizing the Use of Transport Resources and Capabilities}

In this archetype, there are business models oriented towards urban mobility systems that may address the reuse of resources that are typically seen as waste. These include models aimed at collaborative consumption and sharing practices, because one way to recapture wasted value is by maximizing under-utilized assets and resource capabilities [17]. Moreover, these models encourage users to take responsibility for their own consumption practices and recognize sustainable value in sharing practices; car-sharing, lift-sharing, and bicycle-sharing models can be examples of creating value from waste [7].

\subsection{Encouraging Substitution Using Sustainable Modes}

Business models that favor limiting the production of non-renewable resources by seeking other alternatives are part of this archetype. Models that guarantee the commercialization of technological innovations related to substitution through renewable energy sources are important [56,61]. There are also business models that, from a value proposition perspective, encourage sustainable alternatives and reduce car dependence [2], because substitution can be achieved not only through technological aspects but also via user behavior. Customized mobility services according to the user needs and providing real time information are also examples that encourage substitution and make public transportation solutions more competitive and integrated through technological innovations.

\subsection{Offering Service Orientation and Functionality}

The business models included in this archetype aim to satisfy user demands without the ownership of physical goods. This approach fundamentally involves changing the conditions under which materials are produced and transferred, reducing resource consumption and increasing rates of reuse and product durability [17]. Models that are oriented towards service provision and discourage ownership, such as sharing solutions, are also part of this category because they can contribute to changes in consumption and behavior patterns through the use of more sustainable alternatives.

\subsection{Articulating Initiatives that Address the Needs of a Wide Range of Stakeholders in Transport Systems}

Using activities related to value creation, the models represented in this category should articulate the needs of various stakeholders such as users and the government involved in the management of transport systems, seeking the integration of local social needs with institutional policies [25]. Therefore, it is essential to consider the needs of all stakeholders in a business model definition as much as possible, and its success is linked to meeting the expectations of all stakeholders [61]. Thus, business models should address the challenges and needs of one or more local groups, take into account the urban mobility conditions available to these groups, and articulate other actors needed to enable solutions to address these challenges.

\subsection{Reducing Travel Demands}

This archetype includes business models that aim to reduce the demand for travel by delivering alternatives that reduce consumption and contribute to the condition of mobility as a whole. Technological innovations in the field of urban mobility have traditionally simulated increased transport consumption due to a number of structural and economic factors [6]. More recently, technological innovations have allowed the development of solutions that may reduce this consumption demand. For example, people make fewer trips if their work activities can be performed remotely or if they can access services that do not require travel (e.g., telebanking, telemedicine). Moreover, other types of travel can be better served by technological innovation, such as trips involving leisure and large distances, which also have less impact on mobility in large urban centers. 
However, information and communication technologies alone cannot modify travel patterns, indicating that there are opportunities for developing complementary approaches that may be related to travel demand reduction [6].

\subsection{Extending Benefits to Society and to the Environment in a Systemic Perspective}

This archetype contains business models that explicitly deliver social and environmental benefits in their logic of value creation as firms integrate various groups of stakeholders [7,58]. In relation to sustainable urban mobility, solutions are needed that benefit not only the users of mobility systems themselves-that is, customers-but also the environment as a whole. Thus, these solutions are articulated not only from the point of view of technological development associated with products and services but also in terms of other institutional, social, and political elements needed for transitions to sustainable mobility systems. The solutions also contribute to meeting an immediate need without losing sight of a long-term vision, which is a necessary condition for transitions [40].

\subsection{Developing Scale-up Mobility Solutions}

Scale-up solutions for urban mobility involve those that have significant potential to maximize benefits by reaching a wide range of users without costs for this extension to grow proportionally. This archetype includes business models that contribute to the conditions for urban mobility by reaching a large number of people, i.e., through technological applications. These include corporate ride-sharing solutions, mobile applications for instant information that support users in making better transportation decisions, and intelligent transport systems. The potential gains from scale-up solutions are fundamental in the context of sustainable urban mobility since its challenges are much more prevalent in large urban centers with high population density [29,32]. In addition, business models with scale-up potential can contribute to changes in consumption patterns and influence production models, which are closely linked to sustainable urban mobility challenges, since the adoption of highly scalable business ideas by users could encourage many other users to adopt them as well [17].

\section{Conclusions}

The authors initiated an interdisciplinary discussion on the integration of existing concepts within two main research fields-sustainable urban mobility and business models—-to identify the elements that should be considered for creating innovative and sustainable business models in urban mobility. This work therefore contributes to delineating hypotheses that can be subsequently tested in future studies on this theme, that is, validating whether sustainable and innovative business models in urban mobility should address the aspects discussed in each of the intersection aspects analyzed.

Before recognizing current and future challenges, the literature on sustainable urban mobility to some extent legitimizes the importance of articulating business models to ensure the successful introduction and diffusion of sustainable innovations in the field.

However, in relation to guaranteeing the incorporation of a sustainability aspect, there has been little progress in defining which characteristics define these models as actually sustainable, since innovative business models in urban mobility (even with declared sustainable purposes) could lead to negative environmental or social impacts, as to some extent happens to car sharing schemes, which are being criticized by many as an incentive for using private cars instead of public transportation, raising congestion rates in cities, for example.

Although the literature on business models has attempted to define the key terms that can characterize a sustainable business model, in a broader context, little evidence exists regarding how these terms are used in distinct situations, such as urban mobility.

The discussion in this article allows the authors to conclude that the intersection of these fields of research appears to be evident and to define the following aspects by which business models can be directed to incorporate sustainability in urban mobility: favoring the use of clean energy; maximizing the use of transport resources and capabilities; encouraging substitution using sustainable modes; 
emphasizing service orientation and functionality; articulating initiatives that address the needs of a wide range of stakeholders; reducing travel demands; extending benefits to society and to the environment in a systemic perspective; and developing scale-up mobility solutions.

The discussion towards a conceptual intersection between sustainable urban mobility and business models ultimately helps to explain patterns that direct and support the achievement of sustainable urban mobility through business models, contributing to theory, management practice, the development of public policies and, finally, the promotion of sustainable development.

As our main theoretical contribution, we presented a framework from the analysis of the intersection of the literature related to sustainable urban mobility and business models, identifying which aspects should be considered to create sustainable and innovative business models for urban mobility, advancing in proposed model by other research and bringing it closer to the context of sustainable mobility. Part of our contribution was to integrate existing perspectives and building cases and new possibilities for sustainability through sustainable business models approach, as suggested by Bocken et al. as future research agenda opportunities [17].

This framework could also help innovators to develop sustainable innovations in urban mobility, using the characteristics presented in Figure 2 as a guideline to assess sustainability in new business models. Additionally, for policy makers, the aspects for sustainable business models in urban mobility presented above could be a source of guidance to develop incentives and regulations in urban mobility.

However, this study has two notable limitations: only one database (Scopus) was researched, and the practical examples referenced are only illustrative. Future research with empirical data could enrich the aspects that define innovative and sustainable business models for urban mobility and could further examine the factors that favor the incorporation of these aspects throughout the process of proposing, creating, and capturing value, supporting the validation of the theoretical framework presented in this study.

Author Contributions: The argument in this paper was developed from the three authors' (J.V.R.d.S., A.M.d.M. and R.M.) working in a broader research project focused on understanding drivers and barriers for the production organization in the face of the new challenges to sustainable urban mobility transition. J.V.R.d.S. led the writing of the paper.

Funding: This research received no external funding.

Conflicts of Interest: The authors declare no conflict of interest.

\section{Appendix A}

Table A1. Detailed search and selection process.

\begin{tabular}{|c|c|c|c|c|}
\hline Category & $\begin{array}{l}\text { Search Terms in Titles, Abstracts, } \\
\text { and Keywords }\end{array}$ & Filters Applied & $\begin{array}{l}\text { Number of Papers } \\
\text { in Search Results } \\
\text { after Filters }\end{array}$ & $\begin{array}{l}\text { Number of Papers } \\
\text { Selected after } \\
\text { Selection Criteria }\end{array}$ \\
\hline $\begin{array}{l}\text { Sustainable } \\
\text { urban mobility }\end{array}$ & $\begin{array}{l}\text { "sustainable urban mobility" or } \\
\text { "sustainable mobility" or "sustainable } \\
\text { and transport" with "business } \\
\text { model"; "sustainable urban mobility" } \\
\text { or "sustainable mobility" or } \\
\text { "sustainable" with "transport"; }\end{array}$ & \multirow{3}{*}{$\begin{array}{l}\text { - English-only articles } \\
\text { - Blind scientific articles } \\
\text { published in } \\
\text { peer-review journals } \\
\text { - Following sub-areas were } \\
\text { not considered: health, } \\
\text { mathematics, neuroscience, } \\
\text { chemistry, biology, } \\
\text { agricultural and medicine }\end{array}$} & 497 & 33 \\
\hline $\begin{array}{l}\text { Business model } \\
\text { innovation }\end{array}$ & $\begin{array}{l}\text { "business model" and "innovation" } \\
\text { and "review" }\end{array}$ & & 104 & 8 \\
\hline $\begin{array}{c}\text { Sustainable } \\
\text { business model }\end{array}$ & "sustainable business model" & & 95 & 16 \\
\hline
\end{tabular}




\section{Appendix B}

Table A2. Content analysis codes tree ${ }^{1}$.

\begin{tabular}{|c|c|c|c|c|}
\hline $\begin{array}{l}\text { Research } \\
\text { Question }\end{array}$ & $\begin{array}{l}\text { Definitions to Answer } \\
\text { the Research Question }\end{array}$ & Category & Subcategory & Applied Technique \\
\hline \multirow{10}{*}{$\begin{array}{l}\text { What are the } \\
\text { aspects of a } \\
\text { sustainable and } \\
\text { innovative } \\
\text { business model in } \\
\text { the field of urban } \\
\text { mobility? }\end{array}$} & \multirow{4}{*}{$\begin{array}{l}\text { Aspects that characterize } \\
\text { sustainable urban mobility }\end{array}$} & \multirow{4}{*}{$\begin{array}{l}\text { Sustainable } \\
\text { urban mobility }\end{array}$} & $\begin{array}{l}\text { Sustainable urban } \\
\text { mobility challenges }\end{array}$ & \multirow{4}{*}{$\begin{array}{l}\text { Analytic categories and } \\
\text { subcategories obtained from a } \\
\text { inductive approach during } \\
\text { content analysis }\end{array}$} \\
\hline & & & $\begin{array}{l}\text { Sustainable urban mobility } \\
\text { indicators }\end{array}$ & \\
\hline & & & $\begin{array}{l}\text { Management of transitions to } \\
\text { sustainable mobility systems }\end{array}$ & \\
\hline & & & $\begin{array}{l}\text { Role of individual behavior in } \\
\text { mobility systems }\end{array}$ & \\
\hline & \multirow{2}{*}{$\begin{array}{l}\text { Aspects that characterize } \\
\text { innovative } \\
\text { business models }\end{array}$} & \multirow{2}{*}{$\begin{array}{l}\text { Business model } \\
\text { innovation }\end{array}$} & Business models functions & $\begin{array}{l}\text { Analytic categories and } \\
\text { subcategories obtained from a } \\
\text { inductive approach during } \\
\text { content analysis }\end{array}$ \\
\hline & & & Dimensions and key activities & $\begin{array}{l}\text { Analytic categories and } \\
\text { subcategories obtained from a } \\
\text { deductive approach from } \\
\text { literature background. See [16]. }\end{array}$ \\
\hline & \multirow{3}{*}{$\begin{array}{l}\text { Aspects that characterize } \\
\text { sustainable business } \\
\text { models }\end{array}$} & \multirow{3}{*}{$\begin{array}{l}\text { Sustainable } \\
\text { business model }\end{array}$} & Business models functions & $\begin{array}{l}\text { Analytic categories and } \\
\text { subcategories obtained from a } \\
\text { inductive approach during } \\
\text { content analysis }\end{array}$ \\
\hline & & & Dimensions and key activities & $\begin{array}{l}\text { Analytic categories and } \\
\text { subcategories obtained from a } \\
\text { deductive approach from } \\
\text { literature background. See [16]. }\end{array}$ \\
\hline & & & Hinder factors & $\begin{array}{l}\text { Analytic categories and } \\
\text { subcategories obtained from a } \\
\text { inductive approach during } \\
\text { content analysis }\end{array}$ \\
\hline & $\begin{array}{l}\text { Intersection between } \\
\text { sustainable urban mobility } \\
\text { and innovative and } \\
\text { sustainable } \\
\text { business models }\end{array}$ & Not applicable & Not applicable & $\begin{array}{l}\text { Adaptation of the framework of } \\
\text { typologies of sustainable } \\
\text { business models to the context } \\
\text { of urban mobility [17] }\end{array}$ \\
\hline
\end{tabular}

${ }^{1}$ Prepared by the authors. Process of content analysis based on a previous work (see [65]).

\section{References}

1. Spickermann, A.; Grienitz, V.; von der Gracht, H.A. Heading towards a Multimodal City of the Future? Multi-Stakeholder Scenarios for Urban Mobility. Technol. Forecast. Soc. Chang. 2013, 89, 201-221. [CrossRef]

2. Banister, D. The Sustainable Mobility Paradigm. Transp. Policy 2008, 15, 73-80. [CrossRef]

3. Banister, D. Cities, Mobility and Climate Change. J. Transp. Geogr. 2011, 19, 1538-1546. [CrossRef]

4. Beirão, G.; Cabral, J.A.S. Understanding Attitudes towards Public Transport and Private Car: A Qualitative Study. Transp. Policy 2007, 14, 478-489. [CrossRef]

5. Goldman, T.; Gorham, R. Sustainable Urban Transport: Four Innovative Directions. Technol. Soc. 2006, 28, 261-273. [CrossRef]

6. Stead, D. Identifying Key Research Themes for Sustainable Urban Mobility. Int. J. Sustain. Transp. $2013,8318$. [CrossRef]

7. Boons, F.; Lüdeke-Freund, F. Business Models for Sustainable Innovation: State-of-the-Art and Steps towards a Research Agenda. J. Clean. Prod. 2013, 45, 9-19. [CrossRef]

8. Boons, F.; Montalvo, C.; Quist, J.; Wagner, M. Sustainable Innovation, Business Models and Economic Performance: An Overview. J. Clean. Prod. 2013, 45, 1-8. [CrossRef]

9. Evans, S.; Vladimirova, D.; Holgado, M.; Van Fossen, K.; Yang, M.; Silva, E.A.; Barlow, C.Y. Business Model Innovation for Sustainability: Towards a Unified Perspective for Creation of Sustainable Business Models. Bus. Strategy Environ. 2017, 26, 597-608. [CrossRef]

10. Wegener, M. The Future of Mobility in Cities: Challenges for Urban Modelling. Transp. Policy 2013, 29, 275-282. [CrossRef] 
11. World Commission on Environment and Development. Report of the World Commission on Environment and Development: Our Common Future Acronyms and Note on Terminology Chairman s Foreword; World Commission on Environment and Development: Oxford, UK, 1987.

12. Walnum, H.J.; Aall, C.; Løkke, S. Can Rebound Effects Explain Why Sustainable Mobility Has Not Been Achieved? Sustainability 2014, 6, 9510-9537. [CrossRef]

13. Boote, D.N.; Beile, P. Scholars Before Researchers: On the Centrality of the Dissertation Literature Review in Research Preparation. Educ. Res. 2005, 34, 3-15. [CrossRef]

14. Randolph, J.J. A Guide to Writing the Dissertation Literature Review. Pract. Assess. Res. Eval. 2009, 14, 1-13.

15. Mayring, P. Qualitative Content Analysis. Forum Qual. Res. 2004, 1, 159-176.

16. Richardson, J. The Business Model: An Integrative Framework for Strategy Execution. Strateg. Chang. 2008, 17, 133-144. [CrossRef]

17. Bocken, N.M.P.; Short, S.W.; Rana, P.; Evans, S. A Literature and Practice Review to Develop Sustainable Business Model Archetypes. J. Clean. Prod. 2014, 65, 42-56. [CrossRef]

18. Agarwal, O.; Zimmerman, S. Toward Sustainable Mobility in Urban India. Transp. Res. Rec. J. Transp. Res. Board 2008, 2048, 1-7. [CrossRef]

19. Batty, P.; Palacin, R.; González-Gil, A. Challenges and Opportunities in Developing Urban Modal Shift. Travel Behav. Soc. 2015, 2, 109-123. [CrossRef]

20. Mathiesen, B.V.; Lund, H.; Nørgaard, P. Integrated Transport and Renewable Energy Systems. Util. Policy 2008, 16, 107-116. [CrossRef]

21. Pucher, J.; Buehler, R. Cycling towards a More Sustainable Transport Future. Transp. Rev. 2017, 37, 689-694. [CrossRef]

22. Cohen, B.; Kietzmann, J. Ride On! Mobility Business Models for the Sharing Economy. Organ. Environ. 2014, 27, 279-296. [CrossRef]

23. Loo, B.P.Y.; du Verle, F. Transit-Oriented Development in Future Cities: Towards a Two-Level Sustainable Mobility Strategy. Int. J. Urban Sci. 2017, 21, 54-67. [CrossRef]

24. Hrelja, R.; Isaksson, K.; Richardson, T. Choosing Conflict on the Road to Sustainable Mobility: A Risky Strategy for Breaking Path Dependency in Urban Policy Making. Transp. Res. Part A Policy Pract. 2013, 49, 195-205. [CrossRef]

25. Hull, A. Policy Integration: What Will It Take to Achieve More Sustainable Transport Solutions in Cities? Transp. Policy 2008, 15, 94-103. [CrossRef]

26. Akyelken, N.; Banister, D.; Givoni, M. The Sustainability of Shared Mobility in London: The Dilemma for Governance. Sustainability 2018, 10, 420. [CrossRef]

27. Vergragt, P.J.; Brown, H.S. Sustainable Mobility: From Technological Innovation to Societal Learning. J. Clean. Prod. 2007, 15, 1104-1115. [CrossRef]

28. Marletto, G.; Mameli, F. A Participative Procedure to Select Indicators of Policies for Sustainable Urban Mobility. Outcomes of a National Test. Eur. Transp. Res. Rev. 2012, 4, 79-89. [CrossRef]

29. Zito, P.; Salvo, G. Toward an Urban Transport Sustainability Index: An European Comparison. Eur. Transp. Res. Rev. 2011, 3, 179-195. [CrossRef]

30. Macário, R.; Marques, C.F. Transferability of Sustainable Urban Mobility Measures. Res. Transp. Econ. 2008, 22, 146-156. [CrossRef]

31. Doi, K.; Kii, M. Looking at Sustainable Urban Mobility through a Cross-Assessment Model within the Framework of Land-Use and Transport Integration. IATSS Res. 2012, 35, 62-70. [CrossRef]

32. Rodrigues da Silva, A.N.; de Azevedo Filho, M.A.N.; Macêdo, M.H.; Sorratini, J.A.; da Silva, A.F.; Lima, J.P.; Pinheiro, A.M.G.S. A Comparative Evaluation of Mobility Conditions in Selected Cities of the Five Brazilian Regions. Transp. Policy 2015, 37, 147-156. [CrossRef]

33. Geels, F.W. A Socio-Technical Analysis of Low-Carbon Transitions: Introducing the Multi-Level Perspective into Transport Studies. J. Transp. Geogr. 2012, 24, 471-482. [CrossRef]

34. Geels, F.W. From Sectoral Systems of Innovation to Socio-Technical Systems: Insights about Dynamics and Change from Sociology and Institutional Theory. Res. Policy 2004, 33, 897-920. [CrossRef]

35. Hodson, M.; Geels, F.W.; McMeekin, A. Reconfiguring Urban Sustainability Transitions, Analysing Multiplicity. Sustainability 2017, 9, 299. [CrossRef]

36. Ceschin, F. How the Design of Socio-Technical Experiments Can Enable Radical Changes for Sustainability. Int. J. Des. 2014, 8, 1-21. 
37. Köhler, J.; Whitmarsh, L.; Nykvist, B.; Schilperoord, M.; Bergman, N.; Haxeltine, A. A Transitions Model for Sustainable Mobility. Ecol. Econ. 2009, 68, 2985-2995. [CrossRef]

38. Marletto, G. Structure, Agency and Change in the Car Regime. A Review of the Literature. Eur. Transp. Transp. Eur. 2011, 47, 71-88.

39. Kemp, R.; Van Lente, H. The Dual Challenge of Sustainability Transitions. Environ. Innov. Soc. Transit. 2011, 1, 121-124. [CrossRef]

40. Kemp, R.; Avelino, F.; Bressers, N. Transition Management as a Model for Sustainable Mobility. Eur. Transp. Trasp. Eur. 2011, 47, 25-46.

41. de Bruijne, M.; van de Riet, O.; de Haan, A.; Koppenjan, J. Dealing with Dilemma's: How Can Experiments Contribute to a More Sustainable Mobility System? Eur. J. Transp. Infrastruct. Res. 2010, 10, 274-289.

42. Marx, R.; de Mello, A.M.; Zilbovicius, M.; de Lara, F.F. Spatial Contexts and Firm Strategies: Applying the Multilevel Perspective to Sustainable Urban Mobility Transitions in Brazil. J. Clean. Prod. 2015, 108, 1092-1104. [CrossRef]

43. Howarth, C.C.; Polyviou, P. Sustainable Travel Behaviour and the Widespread Impacts on the Local Economy. Local Econ. 2012, 27, 764-781. [CrossRef]

44. Gabrielli, S.; Forbes, P.; Jylhä, A.; Wells, S.; Sirén, M.; Hemminki, S.; Nurmi, P.; Maimone, R.; Masthoff, J.; Jacucci, G. Design Challenges in Motivating Change for Sustainable Urban Mobility. Comput. Hum. Behav. 2014, 41, 416-423. [CrossRef]

45. Teece, D.J. Business Models, Business Strategy and Innovation. Long Range Plan. 2010, 43, 172-194. [CrossRef]

46. Osterwalder, A.; Pigneur, Y. Clarifying Business Models: Origins, Present, and Future of the Concept. Commun. Assoc. Inf. Syst. 2005, 16. [CrossRef]

47. Carayannis, E.G.; Sindakis, S.; Walter, C. Business Model Innovation as Lever of Organizational Sustainability. J. Technol. Transf. 2015, 40, 85-104. [CrossRef]

48. Schneider, S.; Spieth, P. Business Model Innovation: Towards an Integrated Future Research Agenda. Int. J. Innov. Manag. 2013, 17, 1340001. [CrossRef]

49. Zott, C.; Amit, R.; Massa, L. The Business Model: Recent Developments and Future Research. J. Manag. 2011, 37. [CrossRef]

50. Chesbrough, H.; Rosenbloom, R.S. The Role of the Business Model in Capturing Value from Innovation: Evidence from Xerox Corporation 's Technology Spin-off Companies. Ind. Corp. Chang. 2002, 11, 529-555. [CrossRef]

51. Chesbrough, H. Business Model Innovation: Opportunities and Barriers. Long Range Plan. 2010, 43, $354-363$. [CrossRef]

52. Høgevold, N.M. A Corporate Effort towards a Sustainable Business Model. Eur. Bus. Rev. 2011, 23, 392-400. [CrossRef]

53. França, C.L.; Broman, G.; Robèrt, K.H.; Basile, G.; Trygg, L. An Approach to Business Model Innovation and Design for Strategic Sustainable Development. J. Clean. Prod. 2017, 140, 155-166. [CrossRef]

54. Bocken, N.; Short, S.; Rana, P.; Evans, S. A Value Mapping Tool for Sustainable Business Modelling. Corp. Gov. 2013, 13, 482-497. [CrossRef]

55. Bocken, N.M.P.; Rana, P.; Short, S.W. Value Mapping for Sustainable Business Thinking. J. Ind. Prod. Eng. 2015, 32, 67-81. [CrossRef]

56. Jabłonski, A. Scalability of Sustainable Business Models in Hybrid Organizations. Sustainnability 2016, 8, 194. [CrossRef]

57. Matos, S.; Silvestre, B.S. Managing Stakeholder Relations When Developing Sustainable Business Models: The Case of the Brazilian Energy Sector. J. Clean. Prod. 2013, 45, 61-73. [CrossRef]

58. Schaltegger, S.; Hansen, E.G.; Lüdeke-freund, F. Business Models for Sustainability: Origins, Present Research, and Future Avenues. Organ. Environ. 2016, 29, 3-10. [CrossRef]

59. Høgevold, N.; Svensson, G.; Wagner, B.; J. Petzer, D.; Klopper, H.B.; Carlos Sosa Varela, J.; Padin, C.; Ferro, C. Sustainable Business Models: Corporate Reasons, Economic Effects, Social Boundaries, Environmental Actions and Organizational Challenges in Sustainable Business Practices. Balt. J. Manag. 2014, 9, 357-380. [CrossRef]

60. Høgevold, N.M.; Svensson, G.; Padin, C. A Sustainable Business Model in Services: An Assessment and Validation. Int. J. Qual. Serv. Sci. 2015, 7, 17-33. [CrossRef] 
61. Stubbs, W.; Cocklin, C. Conceptualizing a “Sustainability Business Model”. Organ. Environ. 2008, 21, $103-127$. [CrossRef]

62. Upward, A.; Jones, P. An Ontology for Strongly Sustainable Business Models. Organ. Environ. 2016, 29, 97-123. [CrossRef]

63. Birkin, F.; Cashman, A.; Koh, S.C.L.; Liu, Z. New Sustainable Business Models in China. Bus. Strateg. Environ. 2009, 18, 64-77. [CrossRef]

64. Yang, M.; Evans, S.; Vladimirova, D.; Rana, P. Value Uncaptured Perspective for Sustainable Business Model. J. Clean. Prod. 2017, 140, 1794-1804. [CrossRef]

65. Seuring, S.; Müller, M. From a Literature Review to a Conceptual Framework for Sustainable Supply Chain Management. J. Clean. Prod. 2008, 16, 1699-1710. [CrossRef]

(C) 2019 by the authors. Licensee MDPI, Basel, Switzerland. This article is an open access article distributed under the terms and conditions of the Creative Commons Attribution (CC BY) license (http:// creativecommons.org/licenses/by/4.0/). 